\title{
Drill bit selection in a formation with different sedimentary facies using the Markov chain: A case study at one of the oil fields in the south of Iran
}

Rudarsko-geološko-naftni zbornik

(The Mining-Geology-Petroleum Engineering Bulletin) UDC: 622.2

DOI: 10.17794/rgn.2021.2.8

Original scientific paper

\author{
Afsaneh Ghaffari Rad'; Sajjad Negahban' ${ }^{2}$ Behzad Tokhmechi3; Hossein Mostafavi ${ }^{4}$ \\ ${ }^{1}$ Faculty of Mining, Petroleum and Geophysics Engineering, Shahrood University of Technology, Shahrood, Iran. \\ Afsaneh.ghaffarirad@gmail.com, ORCID: 0000-0003-3579-0295 \\ ${ }^{2}$ Faculty of Mining, Petroleum and Geophysics Engineering, Shahrood University of Technology, Shahrood, Iran. \\ s.negahban@shahroodut.ac.ir, ORCID:0000-0002-8548-2357 \\ ${ }^{3}$ Faculty of Mining, Petroleum and Geophysics Engineering, Shahrood University of Technology, Shahrood, Iran. \\ tokhmechi@ut.ac.ir,ORCID:0000-0003-1516-0624 \\ ${ }^{4}$ Exploration Directorate of National Iranian Oil Company, Tehran, Iran. Mostafavi.hossein@gmail.com
}

\begin{abstract}
The selection of a drill bit is an essential issue in well planning. Furthermore, identification and evaluation of sedimentary rocks before well drilling plays a crucial role in choosing the drill bit. Moreover, the Markov chain as a stochastic model is one of the powerful methods for identifying lithological units, which is based on the calculation of the transition probability matrix or transition matrix. The Markov chain experiences transitions from one state (a situation or set of values) to another according to specified probabilistic rules. In this paper, the Markov chain was implemented for bit selection in a formation with different sedimentary facies (such as the Dashtak Formation). Therefore, the proper drill bit was proposed by utilizing the transition matrix of rock facies and the available bits. This process was carried out in two wells where the thicknesses of the Dashtak Formation are 960 meters and 1410 meters. Consequently, the results indicate that the Markov chain is a practical method for selecting bits in a sequence of rock facies based on an acceptable matching between the reality mode (the used bits in the well) and the Markov chain results. Besides, in the case of using an improper bit in a well, and using a bit in a washing and reaming operation, there were differences between the used bits and the Markov chain outputs.
\end{abstract}

Keywords:

Dashtak Formation; drill bit optimization; lithology; transition matrix; sedimentary facies

\section{Introduction}

Drilling oil and gas wells has encountered various challenges from the beginning. New technologies are being discovered to solve critical technical problems in smart and cost-effective ways. Bit selection is one of the important parameters for planning and designing new wells. Choosing a wrong bit or damaging a bit in a well leads to rising drilling costs. Bit selection is a crucial task to perform. There are many aspects that need to be considered and evaluated before the decision is made. There are a lot of parameters in drilling operations that must be evaluated and designed to improve the efficiency of the drilling process (Edalatkhah et al., 2010; Karadzhova, 2014). One of these challenges is selecting the proper bit for different formations (Abbas et al., 2019). The process of drilling a well on the ground requires a drill bit. Indeed, the bit is the fundamental tool used by the drilling engineer and is located at the end of

Corresponding author: Sajjad Negahban

s.negahban@shahroodut.ac.ir the drill string (Baniya, 2018). Choosing the best bit according to the current conditions is one of the most important aspects of drilling engineering. The type of bit and its life determine the cost of drilling and ensure its proper operation (Boryczko, 2012). The Dashtak Formation is a formation with a sequence of different layers. This feature of the Dashtak Formation causes difficulties in bit selection and, likewise, the loss of money and time (Azizi et al., 2008). Therefore, the purpose of this study is to utilize a probabilistic method to select a suitable drill bit in this formation, given that the Markov chain has been introduced as a powerful method for modelling rock facies. Modelling in the Markov chain is performed using the transition matrix (the transfers number from each facies to the other facies or itself is displayed) and the transfer probability matrix (Krumbein and Dacey, 1969).

In recent years, various methods have been proposed for the optimal selection of a drill bit. In the last decade, the application of the Markov chain in the oil industry has attracted significant attention from research teams. Jun et al. in 2012 solved the problem of a three-dimen- 
sional simulation of oil and gas reservoirs using the Markov chain. The results show that this new approach can depict the spatial distribution characteristics of sandstone formations. Subsequently, in 2013, Nikoogoftar et al. proposed the Markov chain model to model lithology units for reservoir management. Validation of the results has shown that the rock facies are modelled with acceptable accuracy. In 2017, Ove Strand used the Markov chain to model the well blowout preventer (BOP) system accurately. This research represented a simple numerical method for solving many experiments for a BOP installation. The present study, the application of the Markov chain probabilistic method in simulating rock facies and selecting a drill bit in one of the Iranian formations was proposed.

\subsection{Geology of the region}

The Lower-Middle Triassic Dashtak Formation is a formation in the Kazerun Group with lithologies of do-

Table 1: The Intervals drilled by used bits in well \#1

\begin{tabular}{|c|c|c|c|c|c|c|c|c|}
\hline Lithology (m) & $\begin{array}{l}\stackrel{\mathscr{B}}{\Xi} \\
\frac{0}{0} \\
\stackrel{0}{\circ}\end{array}$ & 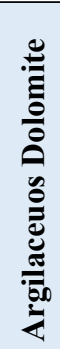 & & 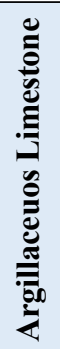 & $\frac{\mathscr{e}}{\frac{\pi}{\mathscr{V}}}$ & 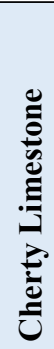 & 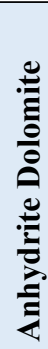 & 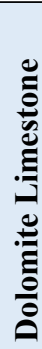 \\
\hline 537 & 168 & 70 & 81 & 20 & 10 & 20 & 0 & 19 \\
\hline 527 & 48 & 55 & 53 & 24 & 48 & 0 & 22 & 0 \\
\hline 214 & 10 & 18 & 26 & 0 & 0 & 25 & 0 & 0 \\
\hline 215 & 0 & 102 & 0 & 0 & 58 & 0 & 0 & 0 \\
\hline 135 & 0 & 0 & 0 & 35 & 0 & 0 & 0 & 0 \\
\hline $517 X$ & 25 & 0 & 0 & 0 & 0 & 26 & 0 & 0 \\
\hline
\end{tabular}

lomite, shale, anhydrite, Argilaceuos dolomite, etc. The lithologies of this formation consist of 6 sequences alternately, such as the section of shale Agar evaporative part A, evaporative part B, evaporative part C, the Sefidar dolomite part, and evaporative part D. Due to the presence of thick anhydrite layers, this formation is considered as an important cap rock in the Zagros Basin for gas reservoirs of the Dahrom Group (Dalan and Kangan) in the south of Iran (Khoshnoodkia et al., 2010; HajianBarzi et al., 2015; Rahmani et al., 2018; Habibnia et al., 2016). In this study, petrophysical and geological information of two wells has been used for modelling. The thickness of the Dashtak Formation in well \#1 and well \#2 is 960 meters and 1410 meters, respectively. Tables 1 and 2 depict the type of used bits and the intervals which were drilled by each bit in wells \#1 and \#2.

\section{Markov chain theory}

The Markov chain is a particular type of Markov process in which the system state selects only discrete values, and it is based on the probability matrix. The future of this process does not depend on the way it was taken in the past, but only on its current position (Awiszus and Rosenhahn, 2018; Kratochv'ıl, 2018). Accordingly, an accidental string of variables $\left\{\mathrm{X}_{\mathrm{t}}, \mathrm{t} \geq 0\right\}$ is called a Markov chain if for all state values $i_{0}, i_{1}, i_{2}, \ldots, i_{t} \in I$, then

$$
\begin{gathered}
P\left\{X_{t+1}=j \mid X_{0}=i_{0}, X_{t+1}=i_{t-1}, \ldots, X_{t}=i\right\}= \\
=P\left\{X_{t+1}=j \mid X_{t}=i\right\}
\end{gathered}
$$

Where the values $i_{0}, i_{1}, i_{2}, \ldots, i_{t}$ are different states in the space of state $\mathrm{i}$ (Brooks et al., 2011; Zhi-zhong et al., 2018; Zakaria et al., 2019).

A one-dimensional series of sequential events by the Markov chain is shown in Figure 1. In this Figure, the

\begin{tabular}{|c|c|c|c|c|c|c|c|c|c|c|c|c|}
\hline Lithology (m) & 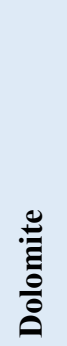 & 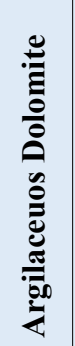 & 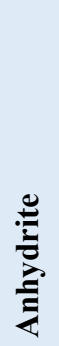 & 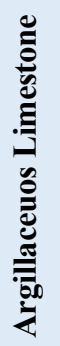 & $\frac{\frac{0}{\pi}}{\tilde{\omega}}$ & 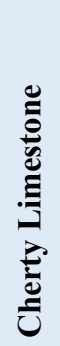 & 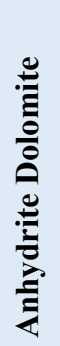 & 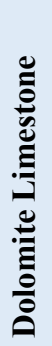 & 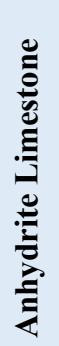 & 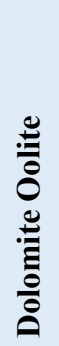 & $\overline{\bar{\Sigma}}$ & 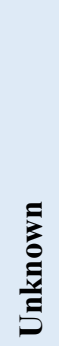 \\
\hline 537 & 97 & 39 & 49 & 37 & 13 & 17 & 0 & 31 & 28 & 0 & 5 & 132 \\
\hline 527 & 102 & 118 & 54 & 4 & 4 & 8 & 4 & 29 & 14 & 4 & 18 & 269 \\
\hline 214 & 4 & 2 & 20 & 0 & 0 & 0 & 0 & 0 & 0 & 0 & 0 & 24 \\
\hline 215 & 22 & 9 & 16 & 5 & 0 & 0 & 0 & 0 & 0 & 0 & 0 & 0 \\
\hline 135 & 0 & 0 & 0 & 0 & 0 & 0 & 0 & 0 & 0 & 0 & 0 & 4 \\
\hline $517 X$ & 73 & 0 & 14 & 0 & 0 & 13 & 13 & 0 & 0 & 0 & 11 & 0 \\
\hline M223 & 36 & 12 & 12 & 0 & 32 & 8 & 0 & 0 & 0 & 0 & 0 & 0 \\
\hline
\end{tabular}

Table 2: The Intervals drilled by used bits in well \#2

\footnotetext{
${ }^{1}$ International Association of Drilling Contractors (IADC)
} 


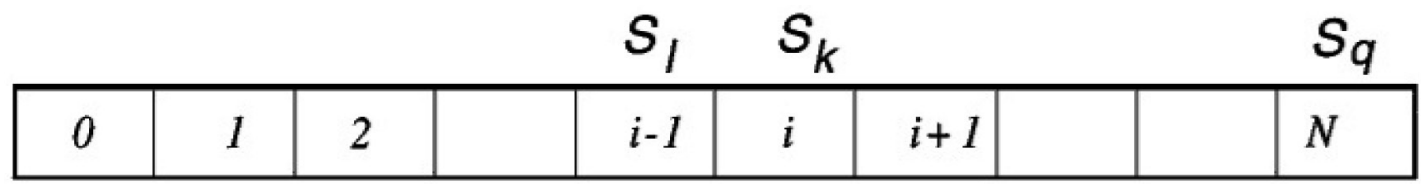

Figure 1: Sequential events for a one-dimensional the Markov chain (Elfeki and Dekking, 2001)

probability of cell $i$ to be in state $S_{k}$, cell i-1 is in state $S_{1}$, and cell $\mathrm{N}$ is in state $\mathrm{Sq}$, and the $\mathrm{S}_{\mathrm{k}}$ event occurs when $\mathrm{Sq}$ and $\mathrm{S}_{1}$ occur. The transition probability from state $\mathrm{i}-1$ to $i$ is expressed by Equation 2 (in this relation, $Z$ represents the cell state).

$$
\mathrm{P}\left(\mathrm{Z}_{\mathrm{i}}=\mathrm{S}_{\mathrm{K}} \mid \mathrm{Z}_{\mathrm{i}-1}=\mathrm{S}_{1}, \mathrm{Z}_{\mathrm{N}}=\mathrm{S}_{\mathrm{q}}\right)
$$

This probability can be written using Equation 3 (Elfeki and Dekking, 2001):

$$
\mathrm{P}\left(\mathrm{Z}_{\mathrm{i}}=\mathrm{S}_{\mathrm{K}} \mid \mathrm{Z}_{\mathrm{i}-1}=\mathrm{S}_{1}, \mathrm{Z}_{\mathrm{N}}=\mathrm{S}_{\mathrm{q}}\right)=\frac{\mathrm{P}_{\mathrm{kq}}^{(\mathrm{N}-\mathrm{i})} \mathrm{P}_{\mathrm{lk}}}{\mathrm{P}_{\mathrm{lq}}^{(\mathrm{N}-\mathrm{i}+1)}}
$$

Where:

$\mathrm{P}_{\mathrm{kq}}^{(\mathrm{N}-\mathrm{i})}$ - the transition probability of state $\mathrm{k}$ to $\mathrm{q}$ with $(\mathrm{N}-\mathrm{i})$ cell interval,

$\mathrm{P}_{1 \mathrm{q}}^{(\mathrm{N}-\mathrm{i}+1)}$ - the transition probability of state 1 to $\mathrm{q}$ with $(\mathrm{N}-\mathrm{i}+1)$ cell interval.
In this study, the Markov chain with discrete state and continuous time was used in one-dimension.

\subsection{Algorithm for rock facies modeling and drill bit selection}

Walter's law states, there is a natural relation between sedimentary environments in which different facies are formed. Thereby, the sequence facies of sedimentary formation are not random and independent of each other (Rink and Thompson, 2015; Blevec et al., 2016). The modelling algorithm of the facies of the Dashtak Formation by the Markov chain is shown in Figure 2. According to this Figure, six steps were defined to go through this algorithm, which are as follows:

Step 1: The state space was determined, according to the variable under study (sedimentary facies of the

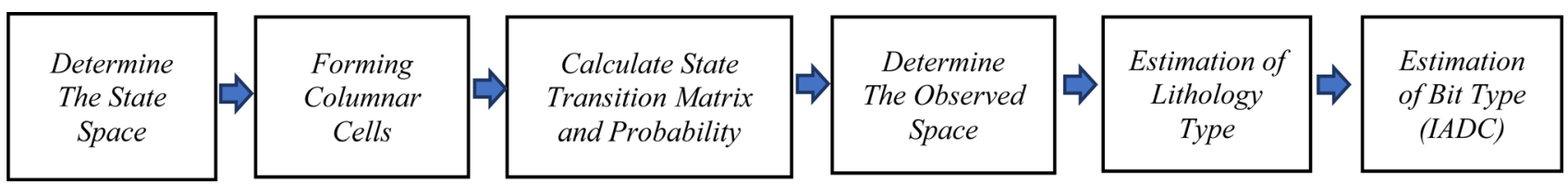

Figure 2: Schematic steps of the proposed model

Table 3: Transfer Matrix or Transition Matrix in well \#1

\begin{tabular}{|l|c|c|c|c|c|c|c|c|}
\hline state & $\boldsymbol{1}$ & $\boldsymbol{2}$ & $\mathbf{3}$ & $\mathbf{4}$ & $\mathbf{5}$ & $\mathbf{6}$ & $\mathbf{7}$ & $\boldsymbol{8}$ \\
\hline $\boldsymbol{1}$ & 230 & 2 & 3 & 0 & 1 & 4 & 1 & 0 \\
\hline $\mathbf{2}$ & 1 & 205 & 1 & 0 & 3 & 0 & 0 & 0 \\
\hline $\mathbf{3}$ & 6 & 2 & 159 & 1 & 0 & 2 & 0 & 1 \\
\hline $\mathbf{4}$ & 0 & 1 & 1 & 105 & 0 & 1 & 0 & 0 \\
\hline $\mathbf{5}$ & 1 & 2 & 1 & 0 & 119 & 0 & 0 & 0 \\
\hline $\mathbf{6}$ & 2 & 0 & 2 & 2 & 0 & 53 & 0 & 0 \\
\hline 7 & 0 & 0 & 1 & 0 & 0 & 0 & 14 & 0 \\
\hline $\boldsymbol{8}$ & 0 & 0 & 1 & 0 & 0 & 0 & 0 & 19 \\
\hline
\end{tabular}

Dashtak Formation) and as a result, state space is equal to the number of existing facies in any sedimentary sequence (Nikoogoftar et al., 2013). According to the lithologies listed in Tables $\mathbf{1}$ and $\mathbf{2}$ for well \#1 and well \#2 respectively, the state space was 8 and 12 members.

Step 2: The data which have been used in this paper, belong to the facies recognized through well log data. According to the resolution of well logs at the wells (the resolution of lithology was 1 meter), according to the thicknesses of the Dashtak Formation at these wells, wells \#1 and \#2 were divided into 960 and 1410 cells, respectively, similar to those represented in Figure 1.

Table 4: Transfer Probability Matrix in well \#1

\begin{tabular}{|l|c|c|c|c|c|c|c|c|}
\hline state & $\mathbf{1}$ & $\mathbf{2}$ & $\mathbf{3}$ & $\mathbf{4}$ & $\mathbf{5}$ & $\mathbf{6}$ & $\mathbf{7}$ & $\boldsymbol{8}$ \\
\hline $\boldsymbol{1}$ & 0.96 & 0.01 & 0.02 & 0 & 0.004 & 0.002 & 0.004 & 0 \\
\hline $\mathbf{2}$ & 0.005 & 0.98 & 0.005 & 0 & 0.010 & 0 & 0 & 0 \\
\hline $\mathbf{3}$ & 0.035 & 0.0115 & 0.93 & 0.006 & 0 & 0.0115 & 0 & 0.006 \\
\hline $\mathbf{4}$ & 0 & 0.00926 & 0.00926 & 0.97222 & 0 & 0.00926 & 0 & 0 \\
\hline $\mathbf{5}$ & 0.01 & 0.02 & 0.01 & 0 & 0.96 & 0 & 0 & 0 \\
\hline $\mathbf{6}$ & 0.038 & 0 & 0.038 & 0.038 & 0 & 0.886 & 0 & 0 \\
\hline $\mathbf{7}$ & 0 & 0 & 0.07 & 0 & 0 & 0 & 0.93 & 0 \\
\hline $\boldsymbol{8}$ & 0 & 0 & 0.05 & 0 & 0 & 0 & 0 & 0.95 \\
\hline
\end{tabular}


Step 3: In this step, the transfer of states from i-1 to i was calculated (i-1 and $i$ were the facies type here, and i-1 may be equal to i) then divided on each row's sum. The transition probability matrix, which shows the probability of transition from state i-1 to state i, was illustrated by Equation 4:

Where:

$$
P_{i-1 i}=\frac{E_{i-1 i}}{T_{i}}
$$

$\mathrm{E}_{\mathrm{i}-1 \mathrm{i}}$ - the transitions from $\mathrm{i}-1$ to $\mathrm{i}$,

$T_{i}$ - the sum of rows $i$,

$\mathrm{P}_{\mathrm{i}-1 \mathrm{i}}$ - the probability of transfer from facies $\mathrm{i}-1$ to facies $i$.

Tables 3 and $\mathbf{4}$ show the number of transfers from each lithology to other lithologies and the probability transfer matrix in well \#1 (Nikoogoftar et al., 2013).

Step 4: In the current step, the location of the observed space (sedimentary facies) was determined. The study field contained geological sections with 960 meters in depth (960, 1-meter cells) and 1410 meters (1410, 1-meter cells). For modelling this section, the information of two wells (similar to Figure 1) was used as the observed space. To estimate the condition of each cell, the vertical transfer matrix of two wells was used.

Step 5: the condition of each cell was estimated using the transfer probability matrix and the observed space. As shown in Equation 3 and Figure 1, each unknown cell $Z_{i}$, using the known states of cells ( $(-1),(N)$ and applying the conditional distribution $\mathrm{P}\left(\mathrm{Z}_{\mathrm{i}}=\mathrm{S}_{\mathrm{K}} \mid \mathrm{Z}_{\mathrm{i}-1}=\mathrm{S}_{\mathrm{l}}\right.$, $\mathrm{Z}_{\mathrm{N}}=\mathrm{S}_{\mathrm{q}}$ ) can be estimated. Cell (i -1$)$ in the previous neighboring $\mathrm{Z}_{\mathrm{i}}$ has the state $\mathrm{S}_{1}$, and cell $(\mathrm{N})$ in the boundary of the formation with the next formation has the state Sq. Regarding these two parameters, the $\mathrm{S}_{\mathrm{K}}$ state in the cell (i) was estimated; In relation 3 of the expressions $\mathrm{P}_{\mathrm{kq}}^{(\mathrm{N}-\mathrm{i})} \mathrm{P}_{\mathrm{lk}}$ the probability of transition from was state $\mathrm{k}$ to state q, which was the power of the difference between the estimated cell distance and the boundary of the next formation $(\mathrm{N}-\mathrm{i})$.

Step 6: In the last step, drill bit selection in the next stage (cell i) was developed by modelling rock facies by the Markov chain (using the transfer probability matrix of two wells) in MATLAB software.

\section{Analysis of Predictions}

Figures 3 to $\mathbf{1 4}$ compare the proposed bit by the Markov chain to the bit actually used in wells \#1 and \#2. Every figure illustrates the used and simulated bits in one well. The red lines represent the interval drilled by the used bit and the blue lines indicate the proposed bit by the Markov chain in an interval. In this research, seven types of drill bits ( 6 types of Roller-Cone Bits and 1 type of Fixed Cutter ( $\mathrm{PDC}^{2}$ ) Bit) have been used. The IADC codes for categorizing roller cone bits based on a 4-character designation which represents the bit's cutting structure, formation compatibility and any special features (Oteri, 2010). The IADC codes for classifying fixed cutter bits comprises both rock properties and structural peculiarities. The designation of each bit includes 4 characters. The first character is the type of cutting structure and matrix material. The second describes the profile of the drill. The third character is characterized by hydraulic solutions. The fourth and final character defines the size and density of the blades (Boryczko, 2012).

There were hard and Chert layers in some depths in well \#2. In these layers, low revolutions per minute (RPM) and high weight on bit (WOB) should be applied to reduce bit erosion. Furthermore, the proper rockbreaking mechanism in such a formation is crushing and scraping (Sherbeny et al., 2016; Akisanmi, 2016; Strasburger et al., 2019). Thereby, the implementation of a PDC bit (M223) in these cases causes severe erosion

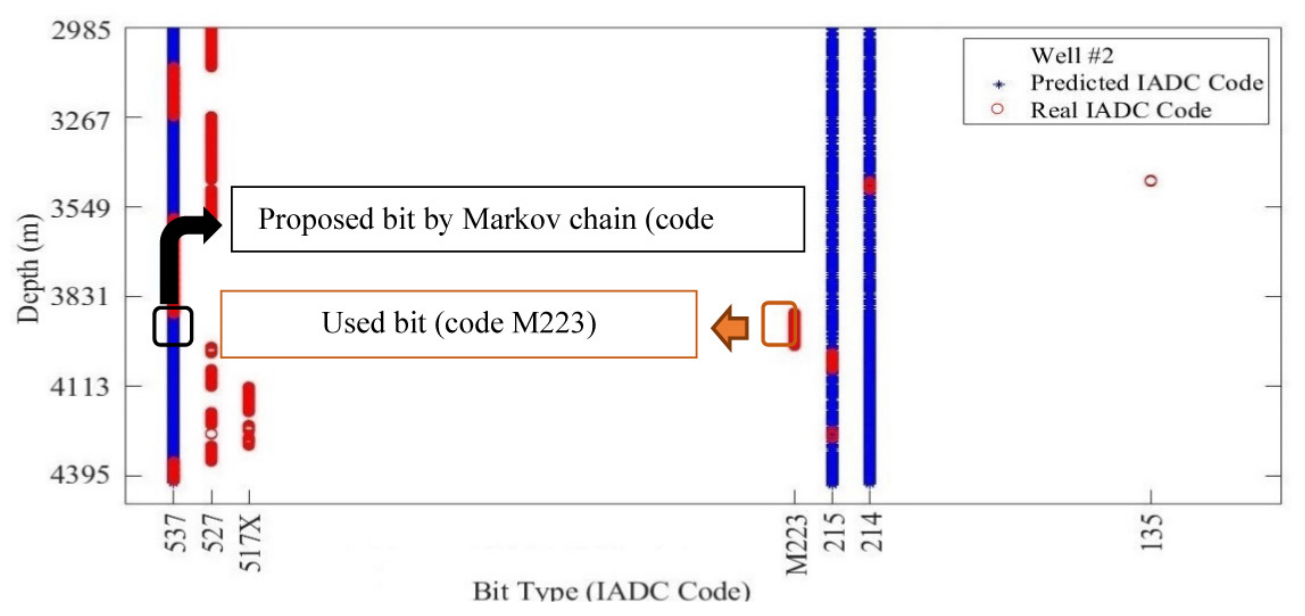

Figure 3: The mismatching of the improper used PDC bit (code M223) with the simulated bit by the Markov (code 537) in well \#2

\footnotetext{
2 Polycrystalline Diamond Compact
} 


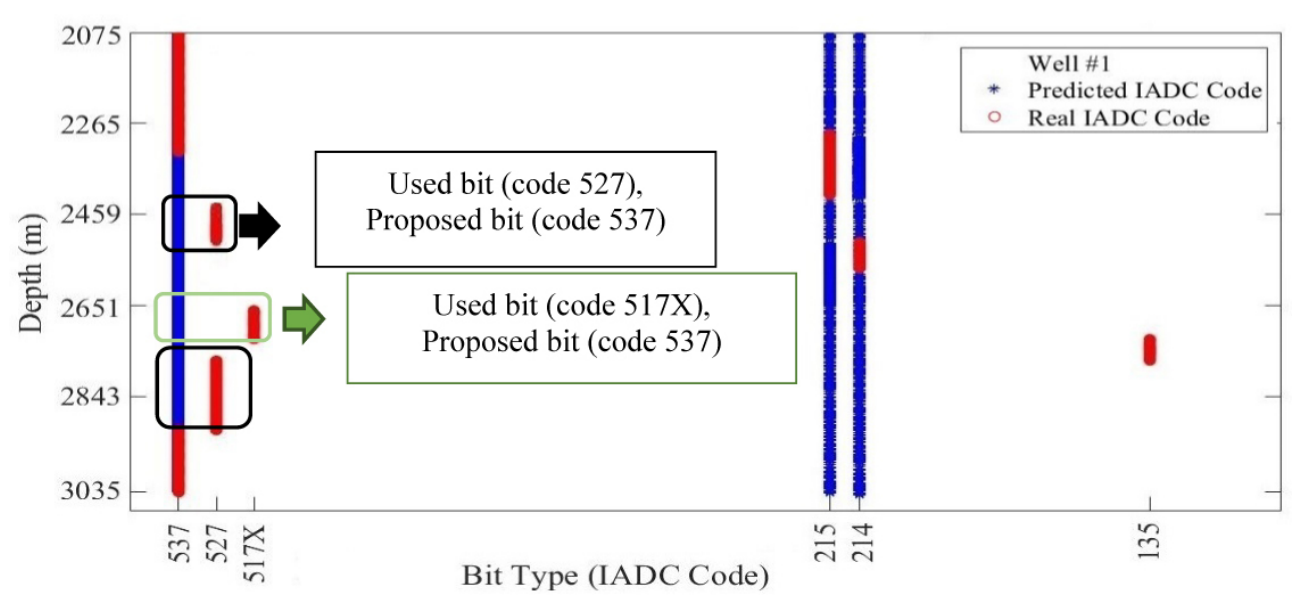

Figure 4: The mismatching between the proposed bit by the Markov chain (code 537) and the improper used bit (codes 527 and $517 \mathrm{X}$ ) in well \#1

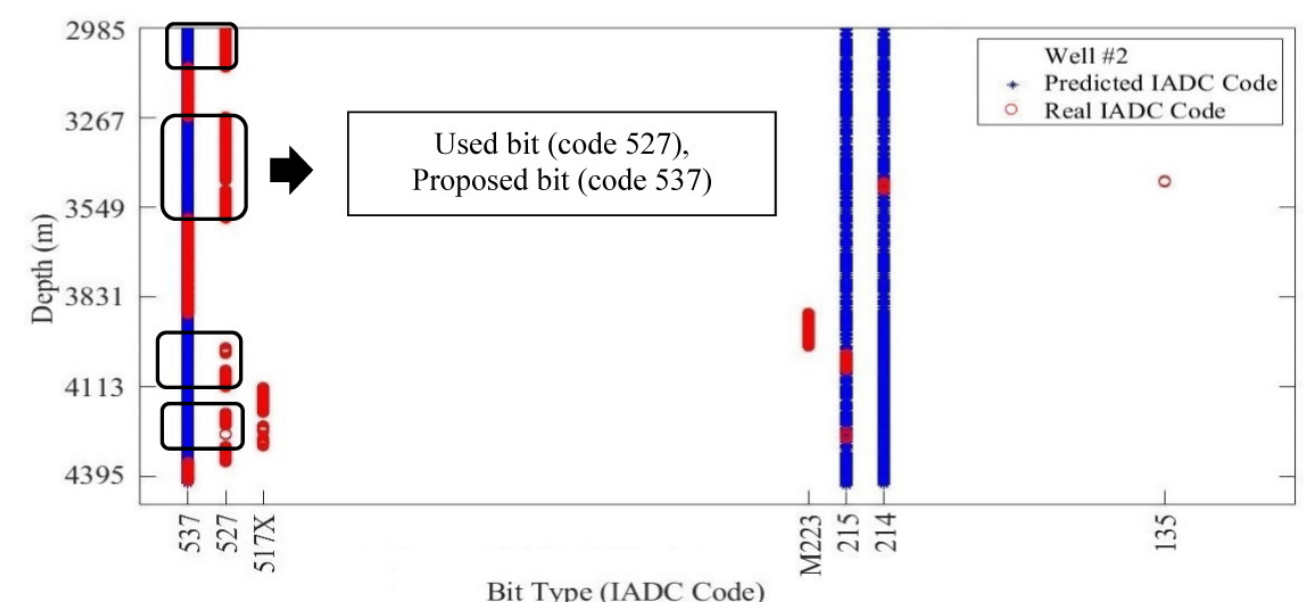

Figure 5: The mismatching between the proposed bit by the Markov chain (code 537) and the improper used bit (codes 527) in well \#2

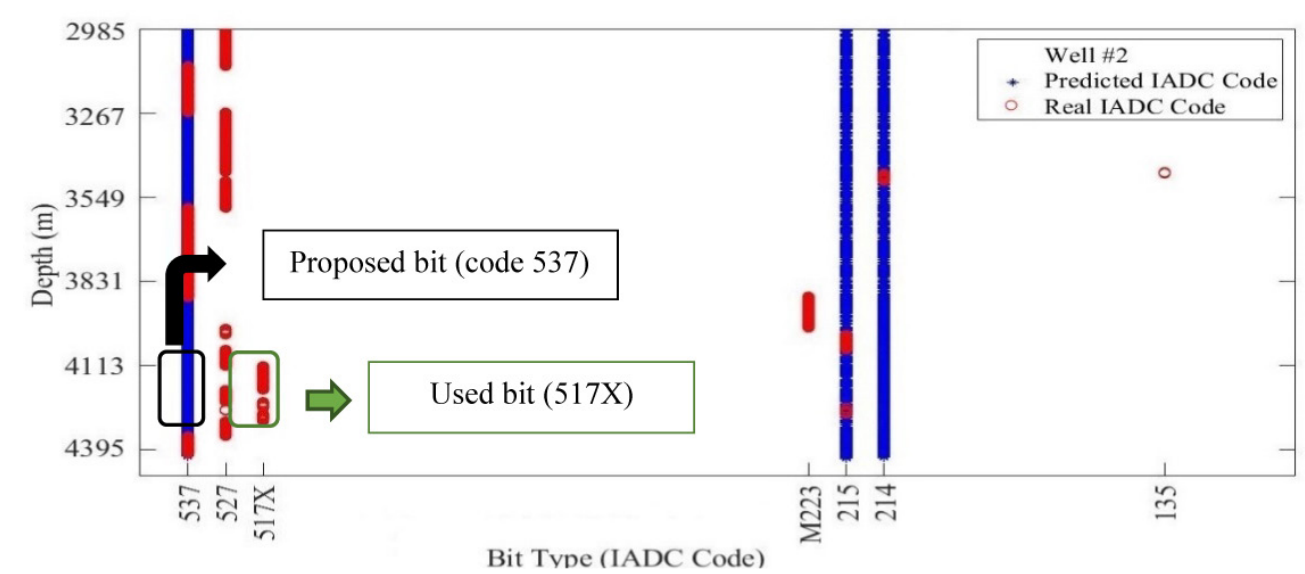

Figure 6: The mismatching between the proposed bit by the Markov chain (code 537) and the improper used bit (codes 517X) in well \#2

of the bit and low drilling speed and consequently, leads the bit to be stuck or lost. According to the above, IADC bit code M223 was not suitable for drilling at this depth in well \#2. As shown in Figure 3, there is mismatching between the improper PDC bit (code M223), which was used in the indicated section and, the simulated bit by the Markov (code 537) in well \#2.

In most cases, the bit with the IADC code 527 was pulled out of the hole, due to high torque, changes in bottom hole assembly, and breaking and damaging of 


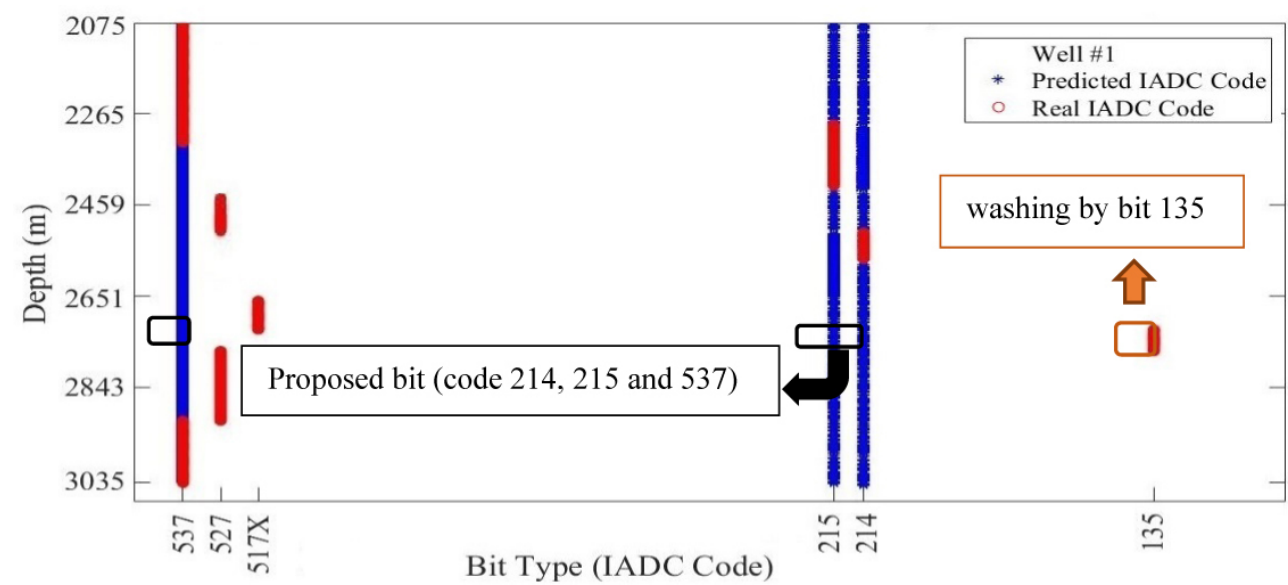

Figure 7: The mismatching between the proposed bits by the Markov chain (code 214, 215, and 537) and the used bit (codes 135) for washing in well \#1

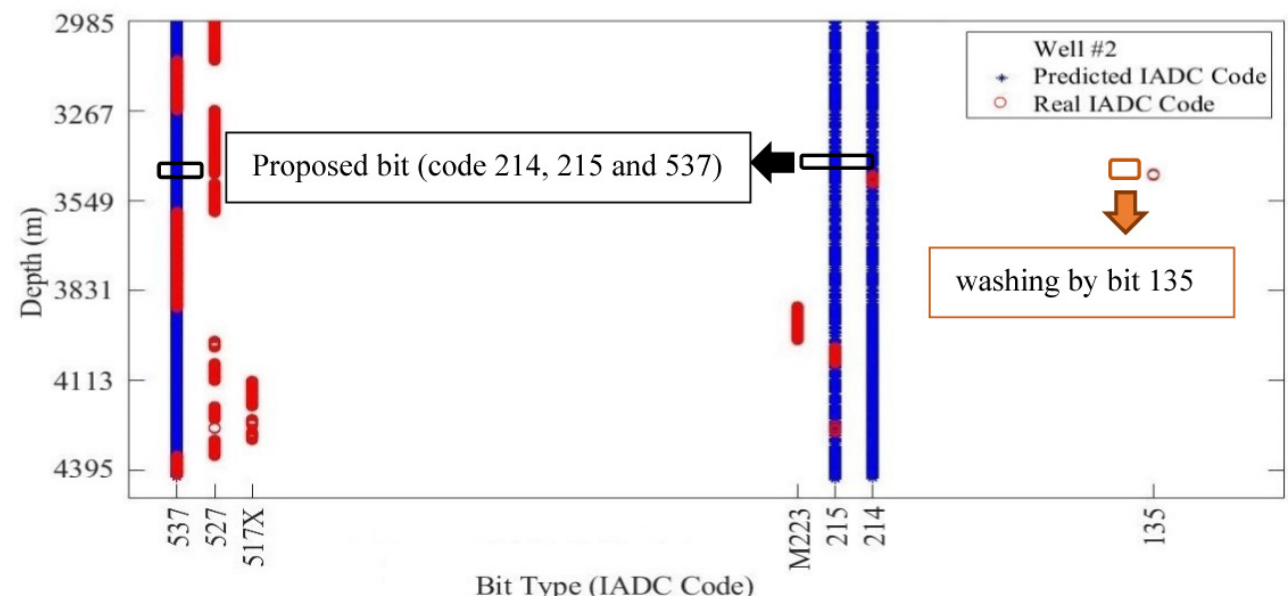

Figure 8: The mismatching between the proposed bits by the Markov chain (code 214, 215, and 537) and the used bit (codes 135) for washing in well \#2

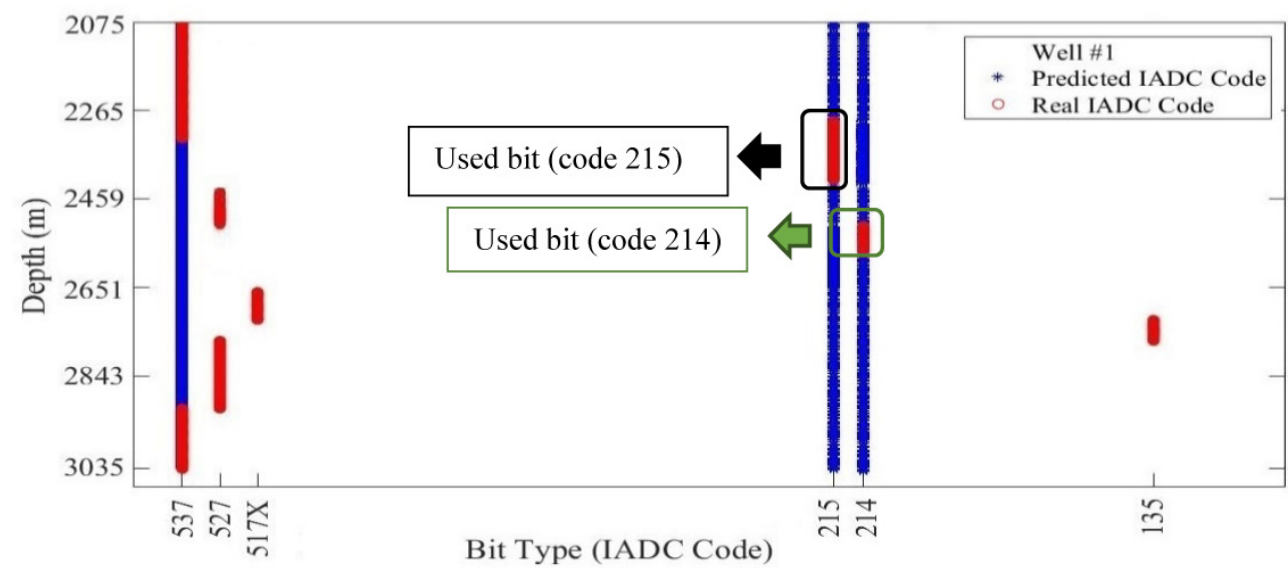

Figure 9: The matching between the proposed bits by the Markov chain (code214, 215) and the used bits (code214, 215) in well \#1

the bit tooth. The drilled lithologies were mostly dolomite, anhydrite, and limestone with moderate and almost similar hardness. Figures $\mathbf{4}$ and $\mathbf{5}$ depict the Markov chain which advised the bit with IADC code 537 according to the wellbore conditions and the available bits, be- cause the drill bit 537 has harder cutters than drill bit 527 and also, the possibility of damaging its tooth is low.

The bit with the IADC code $517 \mathrm{X}$ could not be used in some depths due to the cones having been dropped in the well. The excavated lithology was dolomite, anhy- 


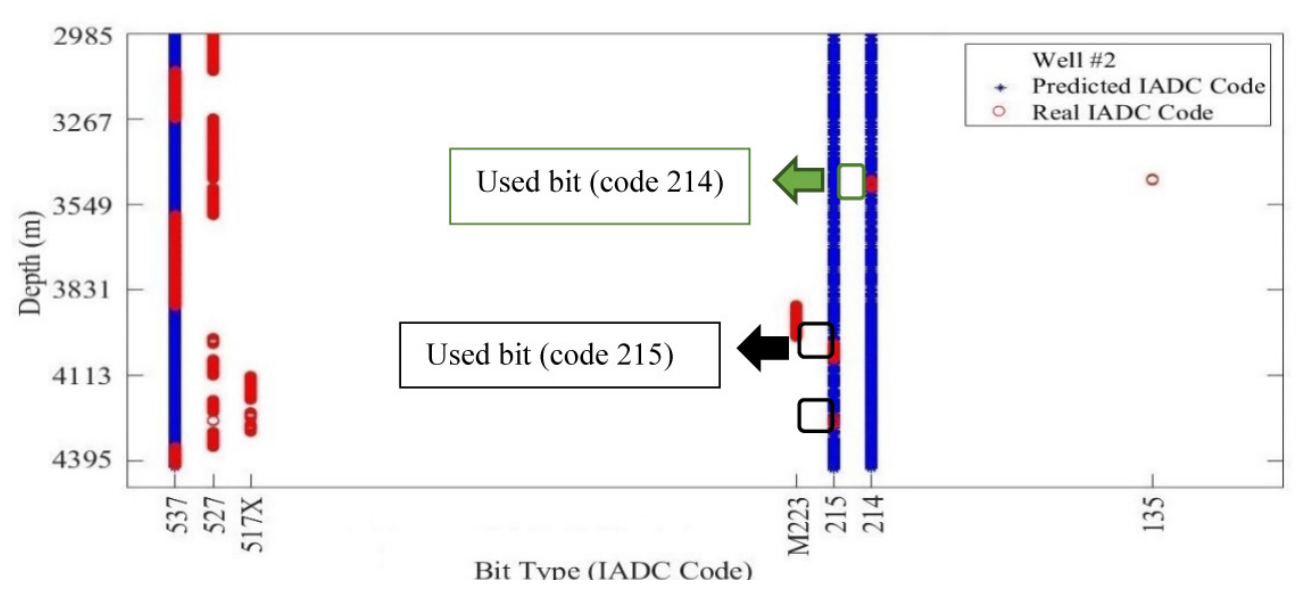

Figure 10: The matching between the proposed bits by the Markov chain (code214, 215) and the used bits (code214, 215) in well \#2

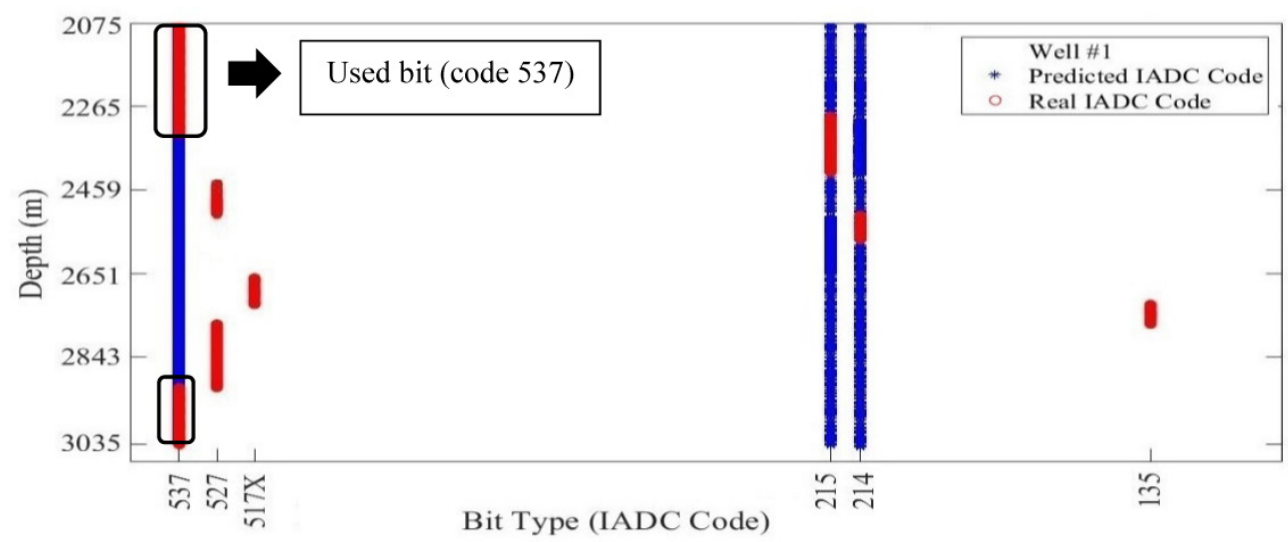

Figure 11: The matching between the proposed bit by the Markov chain (code537) and the used bit (537) in well \#1

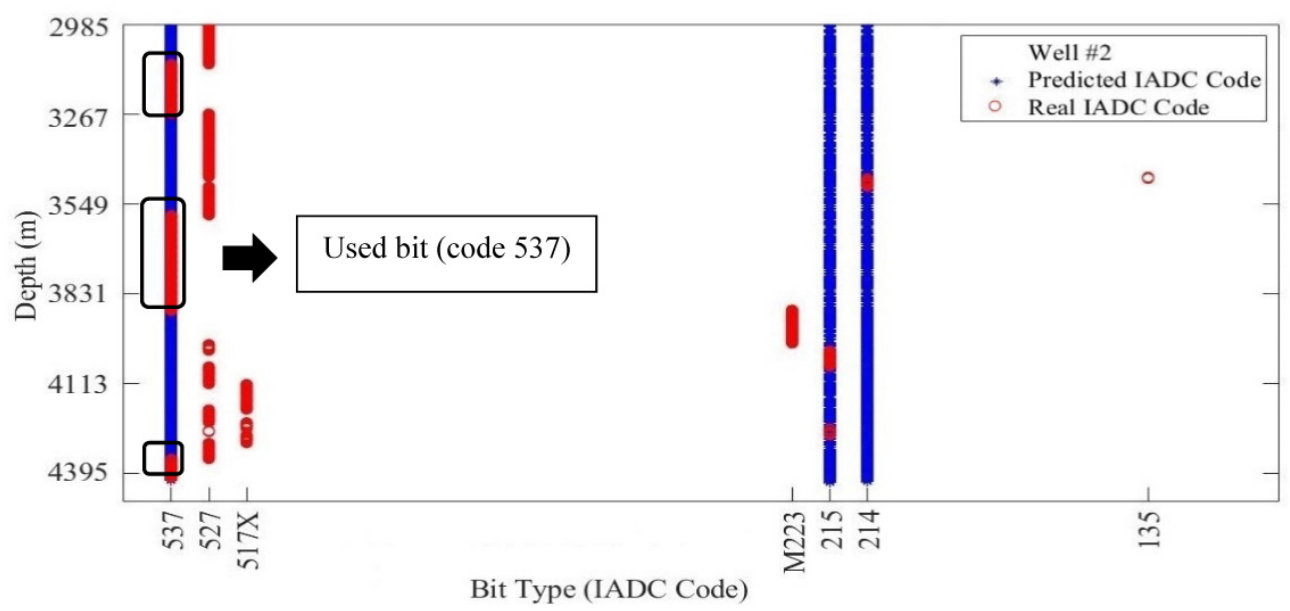

Figure 12: The matching between the proposed bit by the Markov chain (code537) and the used bit (537) in well \#2

drite, and limestone, thus due to the moderate hardness of the formation in this area, the bit was worn out and lost its cone. According to the excavated lithology, the bit with the IADC code 537 was proposed by the Markov chain (see Figures 4 and 6).
The drill bit IADC code 135 has been used in wellbore washing due to the casing operation. Therefore, in the pointed section in Figures $\mathbf{7}$ and $\mathbf{8}$, only the washing and reaming operations were performed. Consequently, 


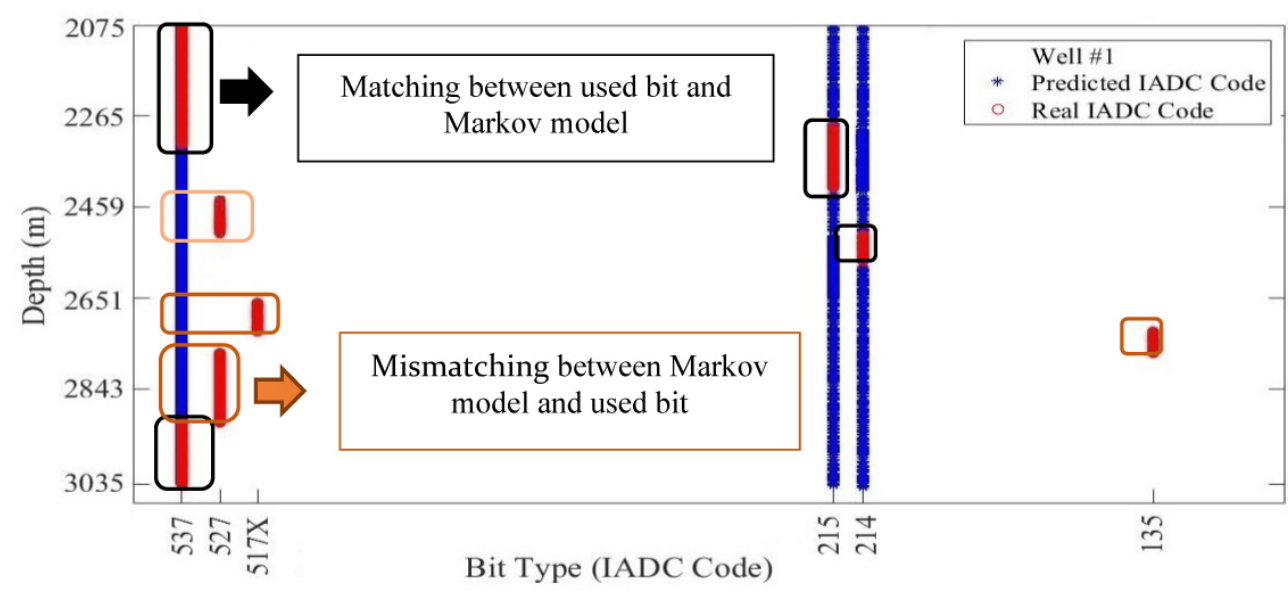

Figure 13: The matching and mismatching between the proposed bit by the Markov chain and the used bit in well \#1

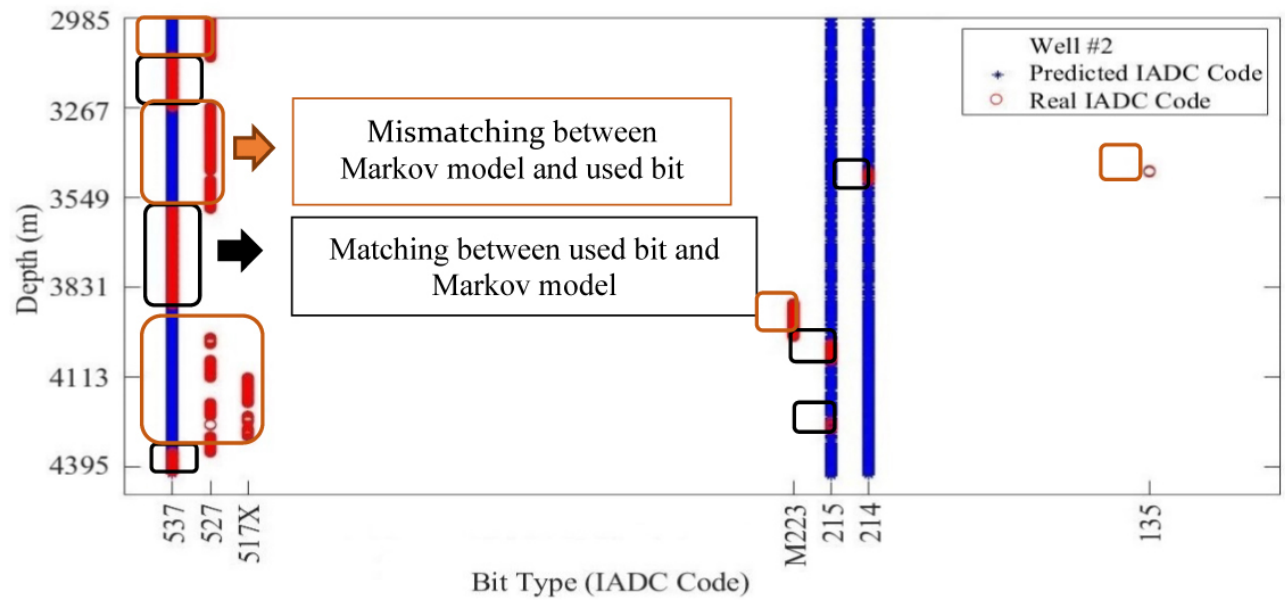

Figure 14: The matching and mismatching between the proposed bit by the Markov chain and the used bit in well \#2

there was a mismatch between the actual bit and the Markov chain prediction.

Drill bit IADC code 215 was used to wash the well after fishing operations in some sections. According to the Markov chain prediction, the application of this bit (drill bit IADC code 215) seems to be a suitable choice due to the lithology and well conditions (as illustrated in Figures 9 and 10).

Drill bit IADC code 214 was utilized to drill the lower and upper cement plugs, in the casing operation. As a result of the well conditions and the Markov chain prediction, which was presented in Figures 9 and 10, the application of drill bit IADC code 214 was appropriate to choose at the indicated part of the wells. However, due to the low $\mathrm{ROP}^{3}$ of these bits, the lithologies of the drilled section, and the weakness of these bits, the application of drill bits IADC code 214 and 215 were proposed for the drilling of cement plugs and were not proposed for drilling a thick formation.

\footnotetext{
${ }^{3}$ Rate Of Penetration
}

The drill bit 537 drilled the borehole without any specific drilling problems, and the operation was done only for drilling and not to solve drilling problems. As mentioned, most of the lithologies of these two wells were drilled with this bit. According to Figures 11 and 12, the Markov chain proposed this type of bit at most depths. The only difference between this type of bit and the two types of drill bits IADC codes 527 and 517X is its cutter hardness, which indicates it was qualified for drilling medium to hard formations such as the Dashtak Formation.

Eventually, in well \#1, as shown in Figure 13, in 580 meters $(60.41 \%)$ of the Dashtak Formation, there was a significant positive correlation between the used bit and the proposed bit. However, in 380 meters, no similarities were found between the used bit and the Markov chain results. Besides, 110 meters of the formation were drilled by drill bit 527, and 160 meters of it were drilled by bit $517 \mathrm{X}$, which according to the available bits and the usable bits in these wells and the given description, bit $517 \mathrm{X}$ could be replaced by bit 537 . Consequently, it can 
be suggested that the bit could adequately be modelled by the Markov chain in $88.54 \%$ of the formation.

In well \#2 (see Figure 14), 58.68\% of the formation $(757 \mathrm{~m})$, which were drilled by the proper bit, were correctly proposed by the Markov chain. On the contrary, $46.31 \%$ of the formation $(667 \mathrm{~m})$ was not precisely modelled by the Markov chain. As mentioned before, this mismatching was due to the use of improper bits or the use of some bit for non-drilling operations, such as washing and reaming. Therefore, in regard to replacing unsuitable bits $(527,517 \mathrm{X})$ with the proper ones ( bit 537) the amount of error could be reduced significantly. In the case of utilizing replaced bits, $75.46 \%$ of similarities could be found between the used bits and the proposed bits.

\section{Conclusion}

The appropriate drill bit selection requires the consideration of various parameters, such as geological and operational factors. In this paper, the facies sequence as a lithology parameter was used to propose the drill bit in drilling engineering. The following conclusions can be drawn from the present study:

- The Markov chain model proposed applying a combination of three types of Roller-Cone Bits IADC code 214, 573, and 215 in wells \#1 and \#2 in the Dashtak Formation.

- The use of a milled tooth bit, such as drill bits IADC code 214 , for well washing, after operations such as fishing and cementing, was proposed by the Markov chain model. Moreover, the Markov chain proposed an insert tooth bit with stronger cutters (such as bit 537) where the hardness of the formation was medium to high. Also, Markov chain proposed this bit type (bit 537) to reduce the cost and time of tripping operations.

- In well \#1, where drilling problems are less frequent than in well \#2, there is $88.54 \%$ similarity between the used bits and the Markov chain results. The existence of $11.46 \%$ error between the used bits and the proposed bits could be due to utilizing bit 135 for non-drilling operations, such as washing and reaming.

- In well \#2, according to the Markov chain results, $75.46 \%$ of the sections of this well were correctly predicted. In addition to the reasons, which were explained for the inaccuracy of the model in well $\# 1$, there were about $24.54 \%$ differences between the proposed bits by the Markov chain and the used bits, due to the lack of sufficient knowledge about the lithology of some sections in well \#2.

\section{References}

Abbas, A.K., Assi, A.H., Abbas, H., Almubarak, H. and Al Saba, M. (2019): Drill Bit Selection Optimization Based on Rate of Penetration: Application of Artificial Neural Networks and Genetic Algorithms. Society of Petroleum Engineers, Conference Abu Dhabi International Petroleum Exhibition \& Conference At Abu Dhabi, United Arab Emirates, 1-11. https://doi.org/10.2118/197241-MS

Akisanmi O.A. (2016): Automatic Management of Rate of Penetration in Heterogeneous formation Rocks. Master's thesis, Faculty of Science and Technology, University of Stavanger, Norway, $117 \mathrm{p}$.

Awiszus, M. and Rosenhahn, B. (2018): Markov Chain Neural Networks. IEEE/CVF Conference on Computer Vision and Pattern Recognition Workshops (CVPRW), Leibniz University Hannover, Germany, 2261-2268. DOI:10.1109/ CVPRW.2018.00293

Azizi, V., Memarian, H. and Khosravi, A. (2008): Bit Selection Optimization for Iranian Oil and Gas Fields. Journal of the Faculty of Engineering, University of Tehran, 42, 5, 553-564.

Baker Hughes Incorporated (2011): IADC Bit Classification. Available from.URL: http://www.bakerhughes.com/newsand media/resources/referenceguides/ iadc-bit-classification

Baniya, S. (2018): Modeling and Simulation of Oil Drilling Activities. Master's thesis, Faculty of Science and Technology, University of Stavanger, Norway, $77 \mathrm{p}$.

Blevec, T.L., Dubrule, O., John, C.M. and Hampson G.J. (2016): Building More Realistic 3-D Facies Indicator Models. the International Petroleum Technology Conference, Bangkok, Thailand, 1-9.

Boryczko, P. (2012): Drill bit selection and optimization in exploration well $6507 / 6-4 \mathrm{~A}$ in the Nordland Ridge Area. Masterıs thesis, Faculty of Science and Technology, University of Stavanger, Norway, 72p.

Brooks, S., Gelman, A., Jones, G. and Meng, X. (2011): Handbook of Markov chain Monte Carlo. London New York, 4-5.

Edalatkhah, S., Rasoul, R. and Hashemi, A. (2010): Bit Selection Optimization Using Artificial Intelligence Systems. Petroluem Science and Technology, 28, 18, 1946-1956. https://doi.org/10.1080/10916460903160818

Elfeki, A.M and Dekking, M. (2001): A Markov Chain Model for Subsurface Characterization: Theory and Applications. Mathematical Geology, 33, 5, 569-589. DOI: 10.1023/ A:1011044812133

Habibnia, B., Hosseini, E., Miri, R., Neshat, J. and AmiriBakhtiar H. (2016): Study of Dashtak and Kangan Formations Boundary Using Geological and Well log Data in South Pars and Kish Gas Fields Located in the Persian Gulf. 3.rd International Conference on Research in Science and Technology, Berlin, Germany, 1-13.

Hajian-Barzi M., Aleali, M., Jahani, D. and Falah-Kheyrkhah, M. (2015): Microfacies, Sedimentary Environment, Sequence Stratigraphy and Strontium Dating of the Dashtak Formation in the Persian Gulf, Fars and Izeh Regions. Scientific Information Database, 24, 95, 185-198.

Jun, L., Xiaojuan, Y., Xiaolong Z. and Liping X. (2012): Lithology stochastic simulation based on the three-dimensional Markov chain model, China National Knowledge Infrastructure. 33, 5, 846- 853. 
Karadzhova G. (2014): Drilling efficiency and Stability Comparison Between Tricone, PDC and Kymera Drill Bits. Master's thesis, Faculty of Science and Technology, University of Stavanger, Norway, 67p.

Khoshnoodkia, M., Mohseni, H., Hajian, M. and FallahKheyrkhah, M. (2010): Biostratigraphy of Dashtak and Khaneh Kat Formations in Zagros Basin. European Association of Geoscientists \& Engineers (GEO). Conference Proceedings, GEO 2010. https://doi.org/10.3997/22144609-pdb.248.304

Kratochv'11, J. (2018): Efficiency of Prague Stock Exchange Market using Markov Chains. Bachelor s thesis, Faculty of Social Sciences, Charles University, Czech Republic, 78 p.

Krumbein, W.C. and Dacey, M.F. (1969): Markov chains and embedded Markov chains in geology. Journal of the International Association for Mathematical Geology, 1, 79-96. https://doi.org/10.1007/BF02047072

Mitchell, R.F. and Miska, S.Z. (2011): FUNDAMENTALS OF DRILLING ENGINEERING. SPE Textbook Series, NO. 12, 326-331.

Nikoogoftar, H., Mehrgini, B., Bahroudi, A. and Tokhmechi, B. (2013): Optimization of the Markov chain for Lithofacies modeling an Iranian oil field, Arabian Journal of Geosciences, 8, 799-808. https://doi.org/10.1007/s12517-013$1152-6$

Oteri, V.A. (2010): Drilling Optimization- Drill Bit Performance Optimization Using DROPS Simulator (Ekofisk/ Eldfisk Field). Master's thesis, Faculty of Science and Technology, University of Stavanger, Norway, 127p.

Ove Strand, G. (2017): Risk Control in the Drilling Phase of Offshore Wells. Doctoral theses, Norwegian University of
Science and Technology Faculty of Engineering, Department of Mechanical and Industrial Engineering. 261p.

Rahmani, O., Khoshnoodkia, M., Mohseni, H. and Hajian, M. (2018): Sequence stratigraphy of the Triassic Period: Case from the Dashtak and Khaneh-Kat Formations, the Zagros Basin, Iran. Journal of Petroluem Science and Engineering, 1- 49. DOI: 10.1016/j.petrol.2018.03.092

Rink, W.J. and Thompson, J.W. (2015): Walther>s Law of Facies. Encyclopedia of Scientific Dating Methods, 957-958. DOI: 10.1007/978-94-007-6304-3_30

Sherbeny, W., Hasan, G., Lindsay, B., Madkour, A., Nagy, A. and Abulawi, M. (2016): Role of Wellbore Imaging and Specific Mineralogy Inputs Data in Bit Selection and Design Softwares, the SPE Kingdom of Saudi Arabia Annual Technical Symposium and Exhibition, Dammam, Saudi Arabia, 1-11. https://doi.org/10.2118/182739-MS

Strasburger, T., Ahmad, R. and Kennedy-Platt C. (2019): Addressing the Drilling Challenges of Midcontinent Chert. URL:https://www.hartenergy.com/exclusives/addressingdrilling-challenges-midcontinent-chert-181029

Zakaria, N.N., Othman, M., Sokkalingam, R., Daud, H., Abdullah, L. and Abdul Kadir, E., (2019): Markov Chain Model Development for Forecasting Air Pollution Index Of Miri, Sarawak. Journal of Sustainability. 11, 19, 1-11. DOI: $10.3390 /$ su11195190

Zhi-zhong, W., Xiang, H. and Yu-ru, L. (2018): Oil-gas reservoir lithofacies stochastic modeling based on one- to threedimensional Markov chains. Journal of Central South University Press and Springer-Verlag GmbH Germany, 25, 6, 1399-1408. https://doi.org/10.1007/s11771-018-3835-3

\section{SAŽETAK}

\section{Odabir dlijeta za bušenje stijena s različitim taložnim facijesima uporabom metode Markovljeva lanca: primjer studije naftnoga polja u južnome Iranu}

Odabir dlijeta iznimno je važan korak u izradi projekta bušotine, a prepoznavanje i procjena taložnih stijena prije početka bušenja ima presudnu ulogu u odabiru dlijeta. Markovljev lanac, kao primjer stohastičkoga modela, jedna je od važnijih metoda za razlikovanje litoloških jedinica. Temelji se na računu matrice vjerojatnosti prijelaza ili matrice prijelaza. Markovljev lanac opisuje prijelaze iz jednoga stanja (situacije ili skupa vrijednosti) u drugo prema određenim vjerojatnosnim pravilima. U ovome je radu prvi put opisana uporaba Markovljeva lanca kod odabira dlijeta za bušenje kroz interval s različitim taložnim facijesima (formacija Dashtak). Stoga su u odabiru odgovarajućega dlijeta korišteni prijelazna matrica stijenskih facijesa i podatci o dostupnim dlijetima. Ovaj postupak proveden je u dvjema bušotinama gdje su debljine formacije Dashtak 960 i 1410 m. Dobiveni rezultati pokazuju da je Markovovljev lanac praktična metoda za odabir dlijeta kod bušenja niza litofacijesa. Zaključak je donesen na temelju stupnja podudaranja između stvarnih podataka (dlijeta korištenih u bušotini) i rezultata dobivenih modelom (Markovljevim lancem). Također, u slučaju uporabe neodgovarajućega dlijeta u bušotini za operacije pročišćavanja i proširenja kanala bušotine pojavile su se razlike između korištenih dlijeta i rezultata dobivenih Markovljevim lancem.

\section{Ključne riječi:}

formacija Dashtak; optimizacija dlijeta; litologija; prijelazna matrica; taložni facijes

\section{Authors contribution}

Afsaneh Ghaffari Rad (Petroleum Engineer): Analysed the data, managed the whole process and supervised it from the beginning to the end. Sajjad Negahban (Assistant Professor): Initialized the idea, collaborated in literature review and participated in the interpretation of the results. Behzad Tokhmechi (Associate Professor): Collaborated in the initiation of the idea, data processing and the interpretation of the results. Hossein Mostafavi (Petroleum Engineer): Collaborated in the initiation of the idea, data gathering and the interpretation of the results. 